\title{
Evaluation of rice genotypes resistance to bacterial leaf blight in Togo
}

\author{
Agnassim BANITO ${ }^{1 *}$, Essohouna Ago KADAÏ ${ }^{1}$, Amos ONASANYA ${ }^{2}$ and \\ Yacouba SÉRÉ ${ }^{3}$ \\ ${ }^{I}$ Ecole Supérieure d'Agronomie, Université de Lomé, BP 2348 Lomé, Togo. \\ ${ }^{2}$ Plant Pathologist, AfricaRice, clo IITA, PMB 5320 Oyo Road Ibadan, Nigeria. \\ ${ }^{3}$ Plant Pathologist - MICCORDEA Project Coordinator AfricaRice, Micocheni B/Kawe, Avocado Street \\ P.O.Box 33581 Dar-es-Salaam, Tanzania. \\ *Corresponding author; Email: bagnassim@hotmail.com; BP: 2348 Lomé, Togo; Tel.: (+228)90033345; \\ Fax: (+228)22218595
}

\begin{abstract}
The present study aimed to evaluate rice genotypes for resistance to bacterial leaf blight caused by Xanthomonas oryzae pv. oryzae. Twenty-one genotypes including six genotypes grown in Togo, two improved genotypes from Africa Rice and thirteen isogenic lines from IRRI were tested. The results revealed differential reactions of genotypes in the expression of the disease. Additive main effect and multiplicative interaction analysis allowed identifying three groups of genotypes according to the level of the disease expression: resistant group made up of the genotype IR24 and all the twelve near isogenic lines tested except the line IRBB5, medium resistant group made up of three genotypes grown in Togo (NERICA4, NERICA8 and NERICA14), the genotype Giganté from AfricaRice, and susceptible group including five genotypes from ITRA (TGR203 and IR841), from AfricaRice (NERICA19 and TOG5681) and the near isogenic line IRBB5 from IRRI. The results provided useful information indicating that none of the grown varieties tested was resistant to BLB, thus revealing a potential risk of epidemics since these genotypes were only medium resistant to susceptible. However, experiments under field conditions in different environments of Togo are needed.

(C) 2012 International Formulae Group. All rights reserved.
\end{abstract}

Keywords: Bacterial leaf blight, rice genotypes, screening, disease resistance.

\section{INTRODUCTION}

Rice is one of the most widely cultivated food crop grown world over. Unfortunately, its production is reduced by many biotic constrains among which Bacterial leaf blight of rice, caused by Xanthomonas oryzae pv. oryzae (Xoo) (Liu et al., 2007; Onasanya et al., 2009), is one of the most widespread and destructive diseases of rice in several countries in tropical rice-growing areas including Africa (Séré et al., 2005; Ouedraogo et al., 2007; Onasanya et al., 2009; Déwa et al., 2011). Bacterial leaf blight of rice was observed to occur in fields with high incidence of 70 to $80 \%$ in several West African countries (Séré et al., 2005). Yield losses due to bacterial leaf blight ranging from 50 to $90 \%$ have been reported (Séré et al., 2005). Recent studies in West African countries such as Burkina Faso, Niger and 
Mali revealed the occurrence of bacterial leaf blight causing significant crop damages (Basso et al., 2011).

In Togo, rice-disease-survey reported the occurrence of bacterial leaf blight in most of rice-growing ecozones with high incidence and severity, and the virulence of the pathogen was determined (Déwa et al., 2011; Kadai 2010). Studies of the resistance of rice varieties have been undertaken (Séré et al., 2005; Ouedraogo et al., 2007; Onasanya et al., 2009). However, investigation on the resistance of rice varieties to bacterial leaf blight has never been initiated in Togo. Therefore, the present study aimed at testing rice genotypes from Togo for resistance to bacterial leaf blight.

\section{MATERIALS AND METHODS}

Plant materials and bacterial strains

Six improved genotypes from Africa Rice Center (WARDA), and two improved genotypes from Institut Togolais de Recherche Agronomique (ITRA, Togo) widely grown in Togo were tested (Table 1). Thirteen near isogenic lines (NILs) with known resistance gene to bacteria leaf blight obtained from the International Rice Research Institute (IRRI) were used as positive control.

The experiment was conducted using 13 X. oryzae pv. oryzae strains from different ecozones of Togo.

\section{Experimental design}

The trial was carried out using the split plot design with 3 replications. Thirteen strains (Table 2) from different ecozones were used to screen 21 genotypes (Table 1) in the screenhouse at Africa Rice Center in Cotonou, Benin. Rice grains were first pregerminated in sterilized Petri dishes under sterile conditions for 5 days and were transplanted in plastic pots. One plastic pot per genotype per Xoo strain in 3 replications was used.

\section{Fertilizer Application}

For fertilization, $1.0 \mathrm{~g}$ of NPK 15-1515 per pot was applied 8 days after transplanting, and $0.2 \mathrm{~g}$ of Urea $46 \%$ per pot was applied 15 days after transplanting.

\section{Bacterial suspension and inoculation}

Inoculum was prepared using a 48-hour old culture of Xoo strains produced on GYCA. The bacteria were harvested from agar plates, suspended in sterile distilled water and adjusted to a concentration of $10^{9} \mathrm{cfu} \cdot \mathrm{mL}^{-1}$ $(\mathrm{OD} 650=0.5)$ prior to use. Inoculation was by clipping method (Kauffman et al., 1973; Séré et al., 2005). The whole leaves of each plant in the plastic pot were clip inoculated 21 days after transplanting.

\section{Data assessment and management}

Evaluation consisted on the measurement of the lesion length due to bacterial leaf blight disease induced by inoculation with each of the strains, and also the measurement of the total leaf length 14 days after inoculation (Séré et al., 2005). From these data, the percentage of lesion length was determined for each inoculated leaf. Disease reactions were categorized according to lesion length. The reactions of differential genotypes were presented as the means of lesion length due to each of the Xoo strains used. For each strain, the reaction of genotypes were classified referring to the methods used by Sanchez et al. (2000), Lee et al. (2003) and Onasanya et al. (2009): resistant $(\mathrm{R})$ - lesion length $<12.5 \%$ and susceptible $(\mathrm{S})$ - lesion length $>12.5 \%$.

\section{Statistical analysis}

Using the percentage lesion length, Analysis of Variance (ANOVA) and additive main effect and multiplicative interaction (AMMI) analysis were performed using IRRISTAT software to genotypes disease 
expression (Aleong and Howard, 1985; Bruckner and Slanger, 1986; Ebdon and Gauch, 2002; Xiaoping and Ognjen, 2005). AMMI analysis was shown to be effective in understanding complex Genotype by Environment interactions trials that are difficult to understand using ordinary ANOVA as recommended by Ebdon and Gauch (2002). The Tukey test (Zhu and Kuljaca, 2005) was performed to compare the means of lesion length scored by different genotypes, thus to classify then.

\section{RESULTS}

The data of the percentage of lesion length due to bacterial leaf blight revealed significant variability $(\mathrm{p}<0.05)$ in the reactions of 21 genotypes to the inoculation with 13 Xoo strains from different ecozones (Table 3). The lesion length caused by inoculation varied from $0.68 \%$ V5 (NERICA14) to about $49 \%$ V8 (TOG5681), with a total of seventeen values $\geq 17 \%$ of lesion length. Significant genotypes $x$ strains interactions $(\mathrm{p}<0.05)$ with Xoo strains from the same locality or ecozone of origin were observed (Table 3). Genotype V2 (IR841) was susceptible to KV4-2 and resistant to KV14-2 from Kovié, V6 (NERICA19) and V8 (TOG5681) were susceptible to DV39-1 and resistant to DV582 from Davié in the Forest savanna transition zone, V3 (NERICA4), V7 (Giganté) and V8 (TOG5681) were susceptible to KT84-2 and resistant to KT83-2 from Kpélé Tutu in the Forest zone, while V1 (TGR203) was susceptible to KM101-1 and resistant to KM129-2 from Koumbéloti and V6 (NERICA19) was susceptible to TN160-2 and resistant to TN135-2 from Tantiégou in the Dry savanna zone. Differential reactions were observed for rice genotypes to Xoo strains from the different ecozones or localites of origin (Table 4). Most of the cultivated rice genotypes were susceptible to strains KT84-2 and TN135-2, while all of them were susceptible to strain TN160-2 from the Dry savanna zone, but were resistant to strains IL23-1, DV58-2, KA63-2, KT83-2, KM101-1 and KM129-2. Also the near isogenic lines revealed resistant reaction to all strains except for V13 (IRBB5) to strains TN135-2 and TN160-2 with lesion length of $13.54 \%$ and $21.19 \%$, respectively (Table 4).

Additive Main effects and Multiplicative Interaction (AMMI) analysis of percentage lesion identify three groups of genotypes according to the level of their reaction to inoculation with Xoo strains (Figure 1): the susceptible genotypes made up of five genotypes V1 (TGR203) and V2 (IR841) from ITRA, V6 (NERICA19) and V8 (TOG5681) from AfricaRice, and the near isogenic line V13 (IRBB5); the medium resistant genotypes made up of three genotypes cultivated in Togo, V3 (NERICA4), V4 (NERICA8) and V5 (NERICA14), and one genotype from AfricaRice, V7 (Giganté); the resistant genotypes made up of only the near isogenic lines with known resistant genes: V9 (IRBB1), V10 (IRBB2), V11 (IRBB3), V12 (IRBB4), V14 (IRBB7), V15 (IRBB8), V16 (IRBB10), V17 (IRBB11), V18 (IRBB13), V19 (IRBB14), V20 (IRBB21) and V21 (IR24).

AMMI analysis revealed that none of the varieties grown in Togo was resistant to bacterial leaf blight even three of these were medium resistant. The genotypes IR841 and NERICA19 which are among the widely grown varieties in the country were susceptible. All the near isogenic lines with known resistant genes were resistant against bacterial leaf blight due to inoculation except IRBB5 which was susceptible. 


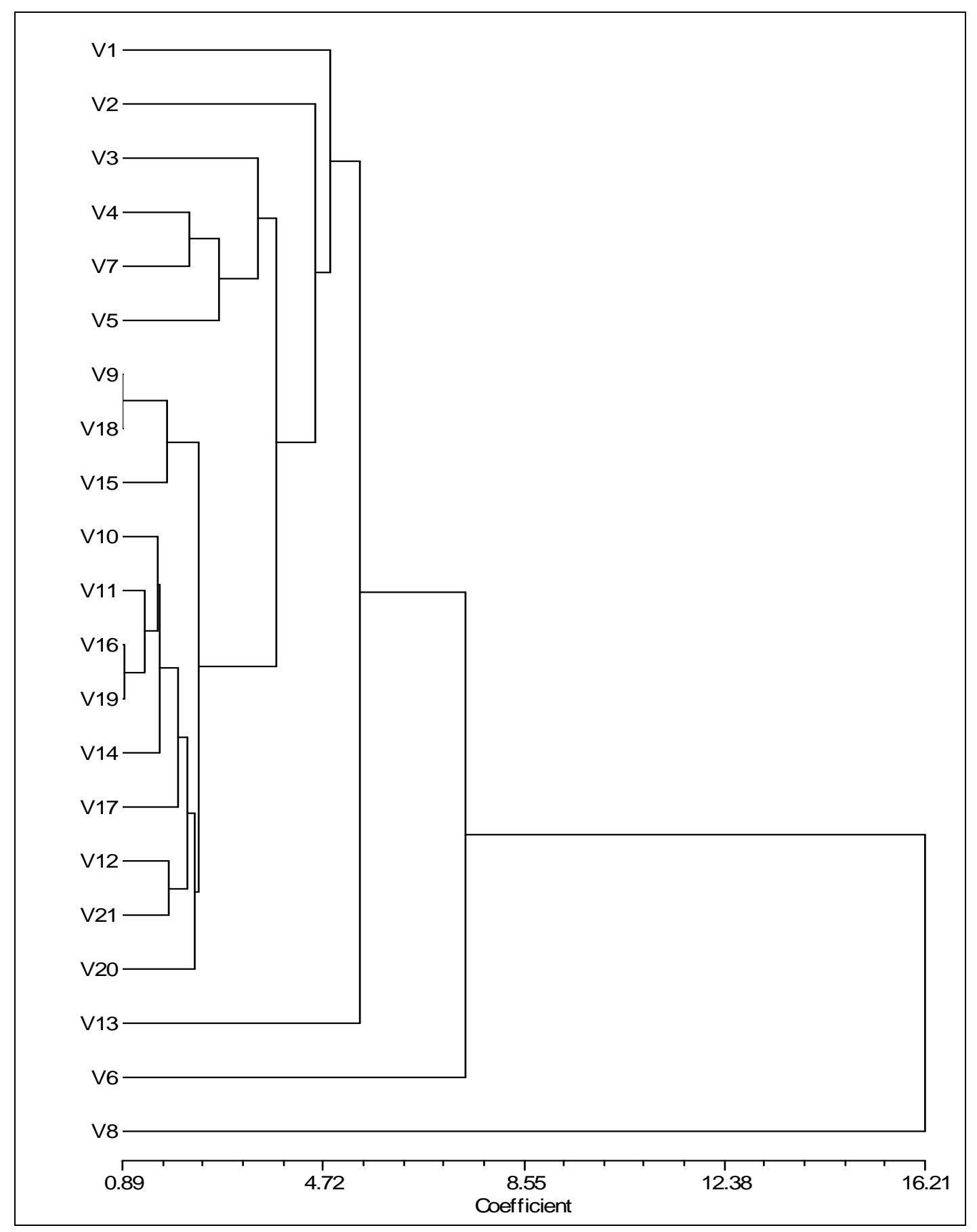

Figure 1: Dendogram of rice genotypes resistance status using AMMI analysis.

Coefficient $=$ Fusion level; genotypes: V1 = TGR203 (WITA4); V2 = IR841; V3 = NERICA4; V4 = NERICA8; V5 = NERICA14; V6 = NERICA19; V7 = Giganté; V8 = TOG5681; V9 = IRBB1; V10 = IRBB2; V11 = IRBB3; V12 = IRBB4; V13 = IRBB5; V14 = IRBB7; V15 = IRBB8; V16 = IRBB10; V17 = IRBB11; V18 = IRBB13; V19 = IRBB14; V20 = IRBB21; V21 = IR24. 
Table 1: List of rice genotypes tested.

\begin{tabular}{lc}
\hline Improved genotypes & Origin \\
\hline TGR203 (WITA4) & ITRA Togo \\
IR841 & ITRA Togo $^{\text {a }}$ \\
NERICA4 & AfricaRice $^{\mathrm{a}}$ \\
NERICA8 & AfricaRice $^{\mathrm{a}}$ \\
NERICA14 & AfricaRice $^{\mathrm{a}}$ \\
NERICA19 & AfricaRice $^{\mathrm{a}}$ \\
Giganté & AfricaRice \\
TOG 5681 & AfricaRice \\
NILs & Resistance genes \\
IRBB1 & Xa-1 \\
IRBB2 & Xa-2 \\
IRBB3 & Xa-3 \\
IRBB4 & Xa-4 \\
IRBB5 & Xa-5 \\
IRBB7 & Xa-7 \\
IRBB8 & Xa-8 \\
IRBB10 & Xa-10 \\
IRBB11 & Xa-11 \\
IRBB13 & Xa-13 \\
IRBB14 & Xa-14 \\
IRBB21 & Xa-21 \\
IR24 & Xa-18 \\
\hline${ }^{a}=$ cultivated in Togo; NILs = near isogenic lines. & \\
\end{tabular}

Table 2: List of $X$. oryzae pv. oryzae strains used for screening 21 rice genotypes for resistance to bacterial leaf blight.

\begin{tabular}{lc}
\hline Strains & Origin \\
\hline KV4-2 & Kovié (Forest savanna transition) \\
KV14-2 & Kovié \\
IL23-1 & Lomé (Forest savanna transition) \\
DV39-1 & Davié (Forest savanna transition) \\
DV58-2 & Davié \\
KA63-2 & Kpélé Atimé (Forest) \\
KT83-2 & Kpélé Tutu (Forest) \\
KT84-2 & Kpélé Tutu \\
SD94-1 & Sodo (Forest) \\
KM101-1 & Koumbéloti (Dry savanna) \\
KM129-2 & Koumbéloti \\
TN135-2 & Tantiégou (Dry savanna) \\
TN160-2 & Tantiégou \\
\hline
\end{tabular}


Table 3: Analysis of variance for percentage lesion length after inoculation with $X$. oryzae pv. oryzae strains.

\begin{tabular}{|c|c|c|c|c|c|}
\hline SV & DF & SS & MS & $\mathbf{F}$ & \\
\hline $\operatorname{Rep}(\mathrm{R})$ & 2 & 3.59 & 1.79 & 2.85 & $\mathrm{~ns}$ \\
\hline Treatment & 272 & 484.28 & 1.78 & 2.82 & ** \\
\hline Genotypes (V) & 20 & 126.74 & 6.34 & 10.05 & $* *$ \\
\hline Strains (I) & 12 & 170.62 & 14.22 & 22.56 & $* *$ \\
\hline V x I & 240 & 186.92 & 0.78 & 1.24 & $*$ \\
\hline Error & 544 & 342.87 & 0.63 & & \\
\hline Total & 818 & 830.75 & & & \\
\hline
\end{tabular}

\section{DISCUSSION}

Bacterial leaf blight of rice was reported in several rice-growing ecozones of Togo with high incidence and severities (Déwa et al., 2011). Therefore, control strategies adapted to environment must be developed to avoid possible epidemics. Among strategies in controlling bacterial diseases such as bacterial leaf blight of rice, host-plant resistance is an important control means. This knowledge on variety resistance is useful for selecting genotypes with durable resistance to the disease (Ouedraogo et al., 2007; Banito et al., 2010). In this study, rice genotypes widely grown in Togo were screened together with near isogenic lines in greenhouse for resistance to bacterial leaf blight by inoculation with 13 strains from various localities in Togo, and variety $\mathrm{x}$ strain interactions were analysed and genotypes were ranked according to level of the disease expression.

Differential reactions of genotypes in the expression of bacterial leaf blight due to inoculation were observed. These reactions revealed differences in characteristics of genotypes. Several research works on the interactions between strains of $X$. oryzae pv. oryzae and rice genotypes have been widely documented (Belkhadir et al., 2004; Lim and Kunkel, 2004; Gu et al., 2005; Ouedraogo et al., 2007; Onasanya et al., 2009). Differential reactions of rice lines to $X$. oryzae pv. oryzae strains were found in Burkina Faso (Ouedraogo et al., 2007). In the present study, AMMI analysis revealed that all grown genotypes tested were medium resistant to susceptible, whereas the near isogenic lines were resistant except IRBB5 which was susceptible. Some strains overcome the resistance of the near isogenic line IRBB5 with gene Xa-5. This confirms results reported by Onasanya et al. (2009) who found IRBB5 susceptible to bacteria strains from 7 African countries. Hoang et al. (2008) also observed differential reactions of rice lines to strains in Mekong Delta. These authors found that rice lines IRBB1, IRBB3, IRBB4, IRBB10, IRBB11 and IRBB14 with known resistance genes were susceptible to all strains of $X$. oryzae pv. oryzae used. Also, studies to assess differential characteristics of 24 near isogenic rice lines with resistance gene to strains from China have been reported (Liu et al., 2007). The authors found 21 days after inoculation that IRBB1, IRBB2, IRBB3, IRBB10, IRBB11 and IRBB14 were the most susceptible of the lines tested. Genotype $\mathrm{x}$ strain analysis revealed differential reactions of 18 rice lines to $50 \mathrm{X}$. oryzae pv. oryzae strains from 7 African countries (Onasanya et al., 2009). These authors found that rice lines 
Table 4: Means percentage lesion length of 21 rice genotypes after inoculation with 13 Xoo strains from different ecozones of Togo.

\begin{tabular}{|c|c|c|c|c|c|c|c|c|c|c|c|c|c|c|c|c|c|c|c|c|c|c|c|c|c|c|c|}
\hline \multirow[b]{2}{*}{ Genotypes } & \multicolumn{26}{|c|}{ Strains } & \multirow[b]{2}{*}{ V-Means } \\
\hline & I1 & & I2 & & I3 & & I4 & & I5 & & I6 & & I7 & & I & 8 & & 9 & I1 & & I1 & & I1 & & I1 & & \\
\hline V1 & 5.02 & $a b$ & 2.47 & $\mathrm{~b}$ & 2.41 & $\mathrm{~b}$ & 5.05 & $\mathrm{ab}$ & 2.68 & $\mathrm{~b}$ & 2.31 & $\mathrm{~b}$ & 7.95 & $a b$ & 9.56 & $\mathrm{ab}$ & 3.62 & $\mathrm{~b}$ & 10.27 & $\mathrm{ab}$ & 2.85 & $\mathrm{~b}$ & 14.47 & $\mathrm{a}$ & 11.50 & $a b$ & 6.17 \\
\hline V2 & 12.35 & $\mathrm{a}$ & 1.31 & $\mathrm{c}$ & 1.60 & $\mathrm{bc}$ & 8,74 & $a b$ & 2.29 & $\mathrm{bc}$ & 2,49 & $\mathrm{bc}$ & 8.22 & $a b c$ & 12.53 & $\mathrm{a}$ & 5.63 & $a b c$ & 1.66 & $\mathrm{bc}$ & 2.31 & $\mathrm{bc}$ & 4.27 & $a b c$ & 6.15 & $a b c$ & 5.35 \\
\hline V3 & 4.99 & $\mathrm{bc}$ & 1.72 & $\mathrm{c}$ & 2.00 & $\mathrm{c}$ & 2.92 & $\mathrm{c}$ & 1.47 & $\mathrm{c}$ & 1.38 & $\mathrm{c}$ & 1.90 & $\mathrm{c}$ & 17.94 & $\mathrm{a}$ & 3.68 & $\mathrm{bc}$ & 1.31 & $\mathrm{c}$ & 1.63 & $\mathrm{c}$ & 4.36 & $\mathrm{bc}$ & 13.11 & $a b$ & 4.49 \\
\hline V4 & 3.62 & $a b c$ & 1.46 & $\mathrm{bc}$ & 4.91 & $a b c$ & 3.05 & $a b c$ & 1.58 & $\mathrm{bc}$ & 5.05 & $a b c$ & 3.62 & $a b c$ & 8.08 & $a b$ & 4.04 & $a b c$ & 1.09 & $\mathrm{c}$ & 2.56 & $\mathrm{bc}$ & 5.57 & $a b c$ & 12.49 & $\mathrm{a}$ & 4.39 \\
\hline V5 & 3.95 & $a b c$ & 1.39 & $\mathrm{c}$ & 2.51 & $\mathrm{bc}$ & 2.18 & $\mathrm{bc}$ & 0.68 & $\mathrm{c}$ & 0.90 & $\mathrm{c}$ & 1.56 & $\mathrm{bc}$ & 1.48 & $\mathrm{c}$ & 5.19 & $a b c$ & 1.54 & $\mathrm{bc}$ & 1.54 & $\mathrm{bc}$ & 8.13 & $a b$ & 12.75 & $\mathrm{a}$ & 3.37 \\
\hline V6 & 3.63 & cde & 12.37 & $a-d$ & 1.51 & $\mathrm{e}$ & 18.93 & $\mathrm{a}$ & 1.41 & $\mathrm{e}$ & 1.47 & $\mathrm{e}$ & 7.52 & b-e & 13.27 & $a b$ & 12.31 & $a b c$ & 2.33 & de & 1.27 & $\mathrm{e}$ & 4.28 & cde & 17.80 & $\mathrm{a}$ & 7.54 \\
\hline V7 & 6.19 & $a b$ & 1.11 & $\mathrm{~b}$ & 2.49 & $\mathrm{~b}$ & 3.93 & $a b$ & 1.49 & $\mathrm{~b}$ & 1.99 & $\mathrm{~b}$ & 1.59 & $\mathrm{~b}$ & 11.02 & $\mathrm{a}$ & 2.26 & $\mathrm{~b}$ & 1.18 & $\mathrm{~b}$ & 1.20 & $\mathrm{~b}$ & 10.10 & $\mathrm{a}$ & 12.63 & $\mathrm{a}$ & 4.40 \\
\hline V8 & 17.62 & $\mathrm{bc}$ & 1.78 & d & 3.11 & $\mathrm{~d}$ & 29.15 & $\mathrm{~b}$ & 5.67 & d & 2.10 & d & 4.20 & $\mathrm{~d}$ & 49.38 & $\mathrm{a}$ & 8.63 & $\mathrm{~cd}$ & 3.16 & d & 2.43 & $\mathrm{~d}$ & 24.96 & $\mathrm{~b}$ & 24.47 & b & 13.59 \\
\hline V9 & 1.40 & $\mathrm{~b}$ & 0.93 & $b$ & 0.83 & $\mathrm{~b}$ & 1.85 & $a b$ & 1.62 & $\mathrm{~b}$ & 0.71 & $\mathrm{~b}$ & 0.97 & $\mathrm{~b}$ & 7.84 & $\mathrm{a}$ & 0.98 & $\mathrm{~b}$ & 1.43 & $b$ & 0.90 & $b$ & 2.16 & $a b$ & 3.47 & $a b$ & 1.93 \\
\hline V10 & 1.34 & $\mathrm{a}$ & 0.91 & a & 1.08 & $\mathrm{a}$ & 1.41 & $\mathrm{a}$ & 0.88 & $\mathrm{a}$ & 0.97 & $\mathrm{a}$ & 2.83 & $\mathrm{a}$ & 2.23 & a & 0.84 & $\mathrm{a}$ & 0.55 & $\mathrm{a}$ & 0.69 & a & 6.12 & $\mathrm{a}$ & 2.88 & $\mathrm{a}$ & 1.75 \\
\hline V11 & 4.18 & $\mathrm{a}$ & 0.93 & $\mathrm{a}$ & 1.68 & $\mathrm{a}$ & 4.70 & $\mathrm{a}$ & 1.67 & $\mathrm{a}$ & 2.13 & $\mathrm{a}$ & 1.20 & $\mathrm{a}$ & 3.57 & $\mathrm{a}$ & 1.57 & a & 0.83 & $\mathrm{a}$ & 1.85 & $\mathrm{a}$ & 5.42 & $\mathrm{a}$ & 2.21 & $\mathrm{a}$ & 2.46 \\
\hline V12 & 2.45 & $\mathrm{~b}$ & 1.59 & $\mathrm{~b}$ & 1.85 & $\mathrm{~b}$ & 1.31 & $\mathrm{~b}$ & 2.02 & b & 1.02 & $\mathrm{~b}$ & 0.98 & $\mathrm{~b}$ & 5.58 & $a b$ & 1.12 & $\mathrm{~b}$ & 1.09 & $\mathrm{~b}$ & 1.22 & $\mathrm{~b}$ & 10.18 & $\mathrm{a}$ & 5.17 & $a b$ & 2.74 \\
\hline V13 & 1.73 & $\mathrm{~b}$ & 1.17 & $\mathrm{~b}$ & 1.83 & $\mathrm{~b}$ & 3.38 & $\mathrm{~b}$ & 2.07 & $\mathrm{~b}$ & 2.29 & $\mathrm{~b}$ & 1.21 & $\mathrm{~b}$ & 1.88 & $\mathrm{~b}$ & 6.22 & $a b$ & 1.11 & b & 1.10 & $\mathrm{~b}$ & 13.54 & $\mathrm{a}$ & 21.19 & $\mathrm{a}$ & 4.52 \\
\hline V14 & 2.11 & $\mathrm{a}$ & 3.08 & $\mathrm{a}$ & 1.98 & $\mathrm{a}$ & 2.65 & $\mathrm{a}$ & 1.29 & $\mathrm{a}$ & 2.57 & $\mathrm{a}$ & 1.51 & $\mathrm{a}$ & 2.27 & $\mathrm{a}$ & 1.63 & $\mathrm{a}$ & 0.62 & $\mathrm{a}$ & 1.10 & $\mathrm{a}$ & 2.67 & $\mathrm{a}$ & 5.68 & $\mathrm{a}$ & 2.24 \\
\hline V15 & 1.68 & $\mathrm{~b}$ & 1.41 & $\mathrm{~b}$ & 2.16 & $\mathrm{~b}$ & 5.59 & $a b$ & 1.04 & $\mathrm{~b}$ & 1.03 & $\mathrm{~b}$ & 2.55 & $\mathrm{~b}$ & 11.48 & $\mathrm{a}$ & 1.59 & $\mathrm{~b}$ & 3.20 & b & 0.92 & $\mathrm{~b}$ & 3.67 & $a b$ & 6.15 & $a b$ & 3.27 \\
\hline V16 & 2.53 & $\mathrm{a}$ & 0.85 & $\mathrm{a}$ & 1.06 & $\mathrm{a}$ & 3.52 & $\mathrm{a}$ & 1.51 & $\mathrm{a}$ & 0.91 & $\mathrm{a}$ & 1.03 & $\mathrm{a}$ & 1.43 & a & 3.23 & $\mathrm{a}$ & 0.70 & $\mathrm{a}$ & 0.86 & $\mathrm{a}$ & 2.31 & $\mathrm{a}$ & 1.56 & $\mathrm{a}$ & 1.65 \\
\hline V17 & 2.20 & $\mathrm{a}$ & 1.13 & $\mathrm{a}$ & 3.15 & $\mathrm{a}$ & 7.81 & $\mathrm{a}$ & 2.21 & $\mathrm{a}$ & 0.78 & $\mathrm{a}$ & 1.57 & $\mathrm{a}$ & 1.48 & a & 2.05 & $\mathrm{a}$ & 0.75 & $\mathrm{a}$ & 1.20 & $\mathrm{a}$ & 6.45 & $\mathrm{a}$ & 5.25 & $\mathrm{a}$ & 2.77 \\
\hline V18 & 2.35 & $\mathrm{a}$ & 1.72 & $\mathrm{a}$ & 1.25 & $\mathrm{a}$ & 3.44 & $\mathrm{a}$ & 1.10 & $\mathrm{a}$ & 1.82 & $\mathrm{a}$ & 2.09 & $\mathrm{a}$ & 7.09 & $\mathrm{a}$ & 0.98 & a & 1.11 & $\mathrm{a}$ & 0.95 & $\mathrm{a}$ & 3.64 & $\mathrm{a}$ & 4.13 & $\mathrm{a}$ & 2.44 \\
\hline V19 & 2.08 & $\mathrm{a}$ & 0.88 & $\mathrm{a}$ & 1.43 & $\mathrm{a}$ & 3.66 & $\mathrm{a}$ & 4.20 & $\mathrm{a}$ & 0.99 & $\mathrm{a}$ & 1.40 & $\mathrm{a}$ & 2.88 & a & 2.69 & $\mathrm{a}$ & 1.36 & $\mathrm{a}$ & 1.09 & $\mathrm{a}$ & 3.14 & $\mathrm{a}$ & 1.98 & $\mathrm{a}$ & 2.14 \\
\hline V20 & 1.83 & $\mathrm{a}$ & 1.08 & $\mathrm{a}$ & 0.92 & $\mathrm{a}$ & 1.62 & $\mathrm{a}$ & 3.35 & $\mathrm{a}$ & 3.57 & $\mathrm{a}$ & 1.77 & $\mathrm{a}$ & 6.11 & $\mathrm{a}$ & 6.46 & $\mathrm{a}$ & 2.96 & $\mathrm{a}$ & 1.20 & $\mathrm{a}$ & 4.74 & $\mathrm{a}$ & 2.13 & $\mathrm{a}$ & 2.90 \\
\hline V21 & 1.91 & $\mathrm{ab}$ & 0.64 & $\mathrm{~b}$ & 2.65 & $a b$ & 2.54 & $a b$ & 3.98 & $a b$ & 3.94 & $\mathrm{ab}$ & 4.42 & $a b$ & 3.71 & $a b$ & 1.86 & $a b$ & 0.85 & $a b$ & 1.03 & $a b$ & 7.55 & $\mathrm{a}$ & 3.85 & $a b$ & 3.00 \\
\hline
\end{tabular}

Strains: I1 = KV4-2; I2 = KV14-2; I3 = IL23-1; I4 = DV39-1; I5 = DV58-2; I6 = KA63-2; I7 = KT83-2; I8 = KT84-2; I9 = SD94-1; I10 = KM101-1; I11 = KM129-2; I12 = TN135-2; I13 = TN160-2

$\mathrm{V} 12=\mathrm{IRBB} 4 ; \mathrm{V} 13=\mathrm{IRBB} 5 ; \mathrm{V} 14=\mathrm{IRBB} 7 ; \mathrm{V} 15=\mathrm{IRBB} ;$; V16 = IRBB10; V17 = IRBB11; V18 = IRBB13; V19 = IRBB14; V20 = IRBB21; V21 = IR24. In each column, values followed with the same

letter are not significantly different at $5 \%$. 
IRBB2, IRBB5, IRBB11 and IRBB21 were susceptible. However, in the present study, the four rice lines were resistant to bacteria strains from Togo. Additionally, rice line IR24 was one of the resistant lines according to the results reported by Onasanya et al. (2009). They also found that the genotypes TOG5681 and Giganté from Africa Rice (WARDA) were among the most susceptible genotypes tested. In the present study, the genotype TOG5681 was susceptible, whereas Giganté was medium resistant. Liu et al. (2007) and Hoang et al. (2008) reported that the rice line IR24 was one of the most susceptible genotypes tested. However, in the present study IR24 revealed resistance to the 13 strains used, confirming the observation of Onasanya et al. (2009) who found that IR24 was one of the resistant lines tested against 50 $X$. oryzae pv. oryzae strains from different countries.

\section{Conclusion}

This study revealed useful information on rice variety $\mathrm{x}$ bacterial strain interactions and differential reactions of genotypes were found. The widely grown genotypes tested were only medium resistant to susceptible, being the potential means of dissemination of bacterial leaf blight of rice over the rice growing areas. This information is useful for the selection of varieties with sustainable resistance to the disease in order to prevent farmers fields from epidemics. However, further studies including trials under field conditions must be undertaken.

\section{REFERENCES}

Aleong J, Howard D. 1985. Extensions of the Duncan's multiple range test for unbalanced data. J. Appl. Stat., 61: 966971.

Banito A, Kpémoua KE, Wydra K. 2010. Screening of cassava genotypes for resistance to bacterial blight using strain x genotype interactions. J. Plant Pathol., 92: 181-186.

Basso A, Onasanya A, Issaka S, Sido AY, Haougui A. 2011. Bacterial leaf blight of rice in Niger: Pathological diversity of isolates collected on irrigated lands. $J$. Appl. Biosci., 38: 2551-2563.

Belkhadir Y, Nimchuk Z, Hubert DA, Mackey D, Dangl JL. 2004. Arabidopsis RIN4 negatively regulates disease resistance mediated by RPS2 and RPM1 downstream or independent of the NDR1 signal modulator and is not required for the virulence functions of bacterial type III effectors AvrRpt2 or AvrRpm1. Plant Cell, 16: 2822-2835.

Bruckner CM, Slanger WD. 1986. Symmetric differences squared and analysis of variance procedures for estimating genetic and environmental variances and covariances for beef cattle weaning weight: I. comparison via simulation. $J$. Anim. Sci., 63: 1779-1793.

Déwa KMK, Banito A, Onasanya A, Kpémoua KE, Séré Y. 2011. Rice bacterial blight in Togo: Importance of the Disease and Virulence of the pathogen. Curr. Res. Bacteriol., 4(3): 94-100.

Ebdon JS, Gauch HG. 2002. AMMI analysis of national turfgrass performance trials. I. Interpretation of genotype by environment interaction. Crop Sci., 42: 489-496.

Gu KY, Yang B, Tian DS. 2005. R gene expression induced by a type-III effector triggers disease resistance in rice. Nature, 435: 1122-1125.

Hoang DD, Nghi KO, Nguyen DT, Pham VD, Le Cam L. 2008. Pathotype profile of Xanthomonas oryzae pv. Oryzae isolates from the rice ecosystem in Cuulong River Delta. Omorice, 16: 34-40.

Kadai EA. 2010. Criblage des varieties améliorées de riz du Togo pour la résistance au flétrissement bactérien en conditions d'infestation artificielles. Mémoire d'ingénieur Agronome, Université de Lomé, 72 p.

Kauffman HE, Reddya PK, Hiesh SPY, Merca SD. 1973. An improved technique for evaluating resistance of rice varieties to Xanthomonas oryzae. Plant Dis. Rep., 57: 537-541.

Lee KS, Rasabandith S, Angeles ER, Khush GS. 2003. Inheritance of resistance to 
bacterial blight in 21 cultivars of rice. Phytopathology, 93: 147-152.

Lim MT, Kunkel BN. 2004. The Pseudomonas syringae type III effector AvrRpt2 promotes virulence independently of RIN4, a predicted virulence target in Arabidopsis thaliana. Plant J., 40: 790-798.

Liu H, Yang W, Hu B, Liu F. 2007. Virulence Analysis and Race Classification of Xanthomonas oryzae pv. oryzae in China. J. Phytopathol., 155: 129-135.

Onasanya A, Ekperigin MM, Nwilene FE, Séré Y, Onasanya RO. 2009. Two pathotypes of Xanthomonas oryzae pv. oryzae Virulence Identified in West Africa. Curr. Res. Bacteriol., 2: 22-35.

Sanchez AC, Brar DS, Huang N, Li Z, Khush GS. 2000. Sequence tagged site marker- assisted selection for three bacterial blight reistance genes in rice. Crop Sci., 40: 792-797.

Séré Y, Onasanya A, Verdier V, Akator K, Ouedraogo LS, Segda Z, Mbare MM, Sido AY, Basso A. 2005. Rice bacterial leaf blight in West Africa: Preliminary studies on disease in farmers fields and screening released varieties for resistance to the bacteria. Asian J. Plant Sci., 4: 577-579.

Zhu X, Kuljaca O. 2005. A short preview of free statistical software packages for teaching statistics to industrial technology majors. J. Ind. Technol., 21: $1-6$. 